\title{
INJURIES IN KIDNEY TISSUE OF THE MUGIL FISH LIZA \\ $R A M A D A$ AS A BIOMARKER FOR ENVIRONMENTAL POLLUTION IN THE LAKE MANZALAH
}

\author{
Shadia M. Kadry ${ }^{1}$; Amal M. Yacoub ${ }^{2}$; Talaat A. Siliem ${ }^{2}$ \\ And Dalia B. Mabrouk ${ }^{2}$
}

1.Department of Zoology, Girls College for Arts, Science and Education.

2.National Institute of Oceanography and Fisheries.

Keywords: Lake Manzalah, pollution, fish, kidney

\begin{abstract}
This study deals with the effect of aquatic environmental pollution of Lake Manzalah on Liza ramada. The fish and water samples were collected seasonally for a year from Autumn 2000 to Summer 2001 from the selected stations near Boughaz El-Gamil. Other water samples were collected from 12 different stations in other locations. The study included heavy metal analysis of the water lake and histopathological changes in the kidneys of the same fish. The investigation revealed that the high values of heavy metals ( $\mathrm{Fe}, \mathrm{Mn}$, $\mathrm{Cu}, \mathrm{Zn}, \mathrm{Pb}$ and $\mathrm{Cd}$ ) encountered during the different seasons in lake Manzalah induced toxic effects on Liza ramada kidneys which may decrease the productivity of this Mugil species. So, it is recommended to try to protect this fish from the destruction by drainage water loaded with agricultural and industrial pollutants as well as sewage.
\end{abstract}

\section{INTRODUCTION}

Lake Manzalah is the largest and most productive lake in the northern region of Egypt. The total area of the lake is about $872 \mathrm{Km}^{2}$. The area of the lake has been steadily decreased in size since records started in the early 1900's where it was estimated as $1647 \mathrm{Km}^{2}$ due to agricultural reclamation activities (Dowidar and Abdel-Moati, 1983; Toews and Ishak, 1984 and Abdel-Baky and El Ghobashy, 1991).

Lake Manzalah is highly dynamic aquatic ecosystem. There are continuous changes in physical, chemical, hydrological and biological properties as early as the beginning of the $20^{\text {th }}$ century. Mean annual salinity declined by about $82.7 \%$ since 1921, from $16.7 \%$ ppt to $2.9 \%$ ppt during $1985 / 86$ (Khalil, 1990). Now, the lake is 
considered as a sink for disposing industrial and human wastes. A total amount of about 7500 million cubic meters of untreated industrial, domestic and drainage water as well as agrochemicals (fertilizers and biocides) is discharged annually into the lake through seven main drains (Ibrahim et al., 1997). Hadous, Ramsis and Bahr El-Bakar drains contribute about $75 \%$ of the total annual drainage water into the southern sector of the lake.

Previous studies on the hydrography and chemical properties of Lake Manzalah have been reported by El Wakeel and Wahby (1970) and Wahby et al. (1972). They concluded that the drainage water changed the nutrient level of the lake in many respects especially the nitrate phosphate ratio.

The residue levels of petroleum hydrocarbons, chlorinated insecticides, polychlorinated biphenyls and organochlorine pesticides in lake Manzalah were studied by Abou-Arab et al. (1995) and Badawy et al. (1995).

Abdel-Satar (2001) studied the effect of drains on the southern of lake Manzalah. The study revealed depletion of dissolved oxygen and high concentrations of nutrients, chemical oxygen demand, biochemical oxygen demand and heavy metals.

As an indicator of exposure to contaminants, histology represents a useful tool to assess the degree of pollution (Bernet et al., 1999). The kidney of fish is a suitable organ for histological examination in order to determine the effect of pollution (Bucher and Hofer, 1993). Many authors reported histopathological abnormalities in kidney of different fish species that were exposed to several pollutants (agricultural, industrial and sewage) (Daskalow et al., 2000 and Lliopoulou \& Kotsani, 2001).

The present study is initiated as a framework to seek an overview of the impact of water pollution in lake Manzalah on the histopathological changes in Liza ramada kidney. In order to proceed to asound assessment of this effect, it was first necessary to monitor the levels of heavy metals pollution in the lake throughout the year by four seasons.

\section{MATERIAL AND METHODS}

\section{A-Collection And Preparation of Water Samples:}

Water samples were collected seasonally from Autumn 2000 to Summer 2001. Twelve stations were selected to cover the area of the lake and divided into four sectors. The location of sampling stations are presented in Fig(1). The samples were collected from 
subsurface layer for heavy metal analysis, each sample was kept into one litre capacity polyethylene bottle.

B-Methods of Heavy Metals Analysis:

The methods described in the American Public health Association APHA (1992), were used for the determination of heavy metals. Samples of heavy metals were digested by conc. Nitric acid. The metals concentrations ( $\mathrm{Fe}, \mathrm{Mn}, \mathrm{Cu}, \mathrm{Zn}, \mathrm{Pb}$ and $\mathrm{Cd}$ ) were determined using Hitachi model 170-30 with Graphite Atomizer (G.A.-2) atomic absorption spectrophotometer and comparing the reading with a standard curve.

\section{C-Histopathological Study:}

Specimens of the mugil species Liza ramada were caught seasonally from Autumn 2000 to Summer 2001 from a station in lake Manzalah (near Boughaz El-Gamil). Kidneys were removed carefully from the collected animals, fixed in $10 \%$ buffered formalin, processed routinely for histological analysis employing haematoxylin and eosin (HE).

\section{RESULTS AND DISCUSSION}

The concentration of iron in lake Manzalah ranged from 0:090 mg. $\mathrm{l}^{-1}$ at station 12 to $2.942 \mathrm{mg} . \mathrm{l}^{-1}$ at station 8 (Table 1). Iron is an abundant and important element, unsurpassed by any other heavy metal in the earth's crust. The increase of iron concentrations of lake water is attributed to the release of Fe from the sediment during the dissolution of Fe.

Like iron, manganese is also known to be essential in primary production. Manganese occurs mostly in the form of soluble $\mathrm{Mn}^{2+}$.It is precipitated as $\mathrm{MnO}_{2}$ by oxidation to $\mathrm{Mn}^{4+}$. It's distribution is thus controlled to a large extent by $\mathrm{PH}$ (Goldberg, 1965). The concentrations of manganese ranged from $0.021 \mathrm{mg} . \mathrm{I}^{-1}$ at stations 11 and 12 to $0.627 \mathrm{mg} .1^{-1}$ at station 5 (Table 2). The United States Public Health Service has set $1 \mathrm{mg} .1^{-1}$ as the drinking water standard (Hutchinson, 1957). The concentrations of $\mathrm{Mn}$ in the present study is significantly lower than the drinking water standard. This indicates that lake Manzalah is devoid of contamination by manganese salts.

Elewa (1993) reported $\mathrm{Mn}$ oxide and hydroxides in the surface sediments under anoxic conditions. This increase may be due to the breakdown of organic matter and dead microorganisms with subsequent release of the metal into water (Prince, 1994). 
The concentrations of copper ranged from $0.007 \mathrm{mgl}^{-1}$ at station 12 to $0.190 \mathrm{mg} \cdot \mathrm{l}^{-1}$ at station 8 (Table 3). Copper is a micronutrient fundamental to all forms of life, in enzyme activity or random rearrangement of natural proteins (Bower, 1979). The metal is insoluble in water, but many of its salts are highly soluble (Anon., 1978). In the drinking water, the limit of $1 \mathrm{mg} .1^{-1}$ copper is based on consideration of taste rather than hazards to health (Masoud et al., 1994). Although prolonged consumption of large doses has been known to cause liver damage in human (National Academy of Science, 1973). It is doubtful that high content of copper could harm human consumers because copper does not tend to accumulate in the edible tissues of fishes (Hassouna, 1989).

Zinc is an essential element and a common pollutant. The minimum concentration of zinc in lake Manzalah was nil at stations2, $6,9,10$ and 12 . The maximum concentration of zinc $\left(0.173 \mathrm{mg}^{-1} \mathrm{l}^{-1}\right)$ was recorded at station 4 (table 4). Mining, surething and sewage disposal are major sources of zinc pollution. Zinc is taken up by fish directly from the water especially by mucous and gills (Skidmore, 1964). The high concentration of zinc at New Bahr El Bakar drain (station 4) may be due to pollution by sewage and industrial wastes discharged in the drain. This can be attributed to the adsorption of zinc hydroxide which binds to organic matter (Abd El-Satar, 1998).

The minimum concentration of lead was nil in different seasons and stations. The maximum concentration was $0.232 \mathrm{mg} .1^{-1}$ at stations 5 and 8 (Table 5).Natural waters seldom contain more than $20 \mathrm{ug} / 1$. the World Health Organization (WHO) international standards for water set $0.1 \mathrm{ppm}$ as a maximum permissible level (MPL) of lead, also the Egyptian Ministry of Health has set $0.05 \mathrm{ppm}$ for fresh water bodies. The annual average values showed that the concentrations of lead were higher than the maximum permissible level (MPL) in the four seasons. The high concentrations of lead may be attributed to the industrial waste inflow.

Lead is a serious cumulative body poison. Lead acts by complexing with oxo-groups in enzymes and affects virtually all steps in the processes of hemosynthesis. It also inhibits acetylcholine esterase, acid phosphatase, ATPase, carbonic anhydrase, etc., and inhibits protein synthesis by modifying transfer RNA. Typical symptoms of lead poisoning are colic, anaemia, headache, convulsion, chronic nephritis of the kidney, brain damage and central nervous system disorder (Greenwood and Earnshaw, 1985). 


\section{DNJURIES IN KIDNEY TISSUE OF L. RAMADA \\ AS A BIOMARKER FOR ENVTRONMENTAL POLLUTION}

The minimum concentration of cadmium was zero in different seasons and stations. The maximum concentration of cadmium was $0.068 \mathrm{mg}^{-\mathrm{I}^{-1}}$ at station 4 in winter season (Table 6). Cadmium concentration of $200 \mathrm{mg}^{-1} \mathrm{l}^{-1}$ is toxic to certain fish (APHA, 1992). The WHO international standards for water sets a maximum permissible level (MPL) of cadmium $0.01 \mathrm{ppm}$. The concentrations of cadmium were higher than MPL at stations $1,3,4,5,6,8,9$, and 11 in the different seasons but the regional annual average $(0.008)$ was lower than MPL. The maximum concentration of cadmium at New Bahr El Bakar drain (station 4) was due to the direct input of sewage, agricultural and industrial wastes. Cadmium is used in various industrial processes, and as a by product of zinc mining, fossil fuel and base metal smelting. This biologically non-essential element is highly toxic to aquatic organisms and is a known renal toxicant (APHA, 1992).

Water pollution induces pathological changes in fishes. Histopathology of kidney of fishes has been a useful tool as an effective indicator in the evaluation of environmental pollution in waters. Kidney is also important for the maintenance of a stable environment with respect to water and salt, excretion and partially for the metabolism of xenobiotics (Bernet et al., 1999).

Kidney structure of fish collected from El Bardawill was not affected and showed normal histological structure (Fig 2.)

In comparison with the controls, kidney of fish collected seasonaly from El Manzalah lake showed many histopathological lesions. During the first season (autumn, 2000) the extent of damage was limited as indicated by a mild increase in Bowman's space and lesser glomerular cellularity (Fig 3.) In addition many proximal convoluted tubules (PCT) and distal convoluted tubules (DCT) acquired wide lumina and showed degenerated epithelial cells with vacuolated cytoplasm and pyknotic nuclei (Fig 4.). The epithelial lining of some tubules was sloughed in their luminae. Degeneration and haemorrhage among the haemopoietic tissue were also realized (Fig 5). The degeneration of the epithelial cells suggested that pollution with heavy metals is highly to affect them since they have their major function in the excretion of divalent ions (Scharperclaus ef al., 1991).

During the following season, (winter, 2001) shrinkage and degeneration of Bowman's capsule, disappearance of urinary space and : distortion of glomerular capillaries with mesangiolysis were seen in many renal corpuscles. Besides, fibrocytes and inflammatory cells 
within intertubular spaces and haemopoeitic tissue were prominent features (Fig 6.). Also many proximal tubules (PT), distal tubules (DT) and convoluted tubules (CT) showed moderate to marked degenerative changes. These tubules acquired irregular lumina, swollen vacuolated and eosinophilic epithelial cells and nuclei exhibiting pyknosis. Other (CT) showed an increase in the number of binucleated cells. Furthermore, some portions of the proximal convoluted tubules showed clear signs of coagulative necrosis (Fig 7.) Necrosis among the haemopoietic tissue was also evident (Fig 8.): Concerning the interstitial haemorrhages and infiltration by chronic inflammatory cells manifested during the present study, it may be attributed to vascular permeability which leads to escape of plasma proteins and white cells indicating inflammatory reactions (Robbins et al., 1981).

In spring 2001, abnormalities included both glomerular tufts and tubular elements. The glomeruli appeared shrunken, atrophied, with densely basophilic nuclei (Fig 9.). Besides, many glomeruli showed hypercellularity and slightly dilated urinary space, while other corpuscles appeared with thickened Bowman's capsules (Fig 10). Loss of normal architecture of renal tubules with cytoplasmic vacuoles and structureless necrobiotic foci were also manifested (fig 11.). In addition, severe damaged tubules displaying necrotic cells with complete lysis of the cytoplasm and pyknosis of their nuclei were noted. Also, thickened dilated renal artery was evident (Fig 12.). Again necrosis of the haemopoeitic tissue and haemolysis of blood cells was seen in between renal tubules, whereas basophilic infiltrative cells were seen invading the lumen of the collecting ductules (Fig 13.).

Renal tissue samples examined during the summer season 2001 manifested degeneration of the kidney constituents. The renal corpuscles appeared partially or completely distorted (Fig 14.). Also, obliteration of Bowman's spaces and vacuolation of glomerular capillary tufts were evident (Fig 15). The renal tubules realized various degree of degeneration. The epithelial cells of some of the (CT) contained pale vacuolated cytoplasm and non-clear cell boundaries. Large necrotic areas were occupied by debris of haemopoietic cells (Fig 16). Complete lysis of some of the renal tubules was evident (Fig 17). In addition, lumina of some tubules possessed cellular debris and hyaline casts. The increased leaking of plasma protein into the glomerular filtrate results in proteinuria and hence the hyaline casts presently reported. Proteinuria is accompanied 


\section{INJURIES IN KIDNEY TISSUE OF L. RAMADA

by escape of the cells in the urine and consequently the formation of hyaline casts (Anderson, 1985). Also, Singhal and Jain (1997) noted that hyaline droplets within the cells of proximal tubules can often appear to displace the nucleus causing nuclear necrosis and represent protein which has been reabsorbed from the glomerular filtrate.

In general, the presently reported histopathological consequences of environmental pollution could be allocated into two categories; intertubular and intratubular ones, beside the obvious impairement of the malpighian corpuscles. The intertubular lesions included the occurance of haemorthagic foci, infiltrative invasion by leucocytes, beside the clear atrophy of the tubules. The intratubular destruction was marked by degenerative changes that shifted progressively to necrobiotic changes. Necrosis noted through the different seasons could be attributed to impaired blood supply due to toxic action of different pollutants in the lake, including heavy metals, specially cadmium which is a known renal toxicant.

The lesions in haemopoietic tissue suggested that both osmotic and ionic regulation were impaired upon exposure to different toxicants (Jarup et al., 1993).

Heavy metals represent part of the major aquatic pollutants, since they are present throughout the ecosystem and are detectable in critical amounts in many parts of the world. Aquatic organisms accumulate and bioconcentrate heavy metals through food and water and various effects might ensue after chronic exposure. Histopathological changes observed during the present study were almost similar to those found in kidney of common carp Cyprinus Carpio following exposure to cadmium (Singal and Jain, 1997). Also, cadmium exposure induced fibromas in kidney of rainbow trout, while mercury caused kidney granulomas in the same fish (Lliopoulou and Kotsanis, 2001). Also, similar histopathological lesions were observed in kidney of fish under the effect of different toxicants. Haemosiderosis, occurring as pigmented melanomacrophage centers, was the main lesion observed in kidney of flounder exposed to oil-contaminated sediment (Khan, 1995). Haemosiderosis was also evident in kidney of Pleuronectes americanus taken from oil-contaminated sites (Khan, 1998). However, alterations in kidneys of waste water exposed trout was restricted mainly to the tubules and were attributed to high levels of un-ionized ammonia (schmidt et al., 1999). Also, the macrophage aggregates which appear in the kidney of four species of benthic fish 
sampled in 1997 and 1998 was attributed to the stressors which might be associated with the indiscriminate disposal of petroleumcontaminated bilge water by fishing boats over the last five decades (Khan, 2000).

In the present study, the high levels of heavy metals encountered in the different seasons, indicates that these values exceed the allowable maximum concentration reported by World Health organization which may cause a public health problem (ElNaggar et al., 2000). The histological lesions in kidney of Liza ramada were concomittant with these levels.

Finally, evidence presented indicates that the drains play an important role in increasing the eutrophication condition of the lake water which causes serious effects on aquatic organisms. The presently reported nephrotoxicity in Liza ramada induced by different pollutants in lake Manzalah decreases the productivity of the fish.

It is expected that kidney lesions and their magnitude would show distinct seasonal variation. Nevertheless, as for as the hydrography of the lake Manzalah is concerned, it represents a closed lake with an almost constant water level. Hence the concentration of heavy metal's pollutants showed insignificant variations throughout the yearly seasons.

Consequently, histopathological changes of the kidney showed that minor differences. Nevertheless, it may be concluded that the kidneys of fish could be ranked as biomarker of pollution. So it is recommended to try to protect this fish from the destruction by drainage water loaded with agricultural and industrial pollutants as well as sewage.

\section{ACKNOWLEDGEMENT}

The authors are deeply grateful to Prof. Madiha A. Asshry, professor of histochemistry, Girl's college for Arts, Science and Education, Ain Shams University for her valuable comments, her grateful advice and critically reviewing the manuscript.

\section{REFERENCES}

Abdel Moati, M. A. R. (1985). Studies on the chemistry of lake Manzalah water. Ph. D. Thesis, Fac. Sc., Alex. Univ., Egypt. 
Abdel-baky, T. E. and El-Ghobashy, A. A. (1991). Seasonal variation of mineral contents in four species of cichlid fishes from lake Manzala, Egypt. J. Egypt. Ger. Soc., Zool., 6 (A): 283-296.

Abdl El-Satar, A. M. (1998). Distribution of some elements in River Nile environment at Great Cairo Region. Ph. D. thesis, Fac. Sci, Cairo Univ.

Abdel-Satar, A.M. (2001). Environmental studies on the impact of the drains effluent upon the southern sector of lake Manzalah, Egypt. Egypt. J. Aquat. Biol. \& Fish., 5(3): 17-30.

Abou-Arab, A. A. K. ; Ayesh, A. M. ; Amra, H. A. and Naguib, K. (1995). Some pesticides and heavy metals contents of imported fish (Sardin and Mackerel) in Egyptian markets. J. Agric. Sci., Mansoura Univ., 20(11): 4735-4796.

Adams, M. B. ; Powell, M.D. and Purser, G.Y. (2001). Effects of acute and chronic ammonia and nitrite exposure on oxygen consumption and growth of juvenile big bellied seahorse. J. of Fish Biol., 58: 848-860.

American Public Health Association (APHA), (1992). Standard Methods for the Examination of Water and Waste Water. New York.

Anderson, J. (1985). Urinary system. In. Muir's Textbook of Pathology, $12^{\text {th }}$ ed. English Language. Book Society, Edward Arnold, 2224.

Anon. (1978). Water supply, treatment and distribution. Library of congress cataloging in publication data, Wallker. Rodger.

Badawy, M. I. ; Wahaab, R. A. and Waly, H. F. (1995). Petroleum and chlorinated hydrocarbons in water from lake Manzalah and associated canals, Bull. Environ. Contam. Toxicol., 55(2):258263.

Bernet, D. ; Schmidt, H. ; Meier, W. ; Burkhardt- Holm, P. and Wahli, T. (1999). Histopathology in fish: proposal for a protocol to asses aquatic pollution. J. Fish Dis., 22; 25-34. 
Bower, J. J. M. (1979). Environmental Chemistry of the Elements. Academic press. London.

Bucher, F. and Hofer R. (1993). The effects of treated domestic sewage on three organs (gills, Kidney, Liver) of brown trout (Salmo trutta). Water Research, 27: 255-261.

Daskalov, H. ; Robertson, P. A. W. and Austin, B. (2000). Influence of oxidized lipids in diets on the development of rainbow trout by syndrome. J. Fish Dis., 23 (7-14).

Dowidar, M. N. and Abdel-Moati, A. R. (1983). Distribution of nutrient salts in lake Manzala. Egypt. Rapp. Comm. Int. Medit., $28(6)$ : 185-188.

Elewa, A. A. (1993). Distribution of $\mathrm{Mn}, \mathrm{Cu}, \mathrm{Zn}$ and $\mathrm{Cd}$ in water, sediments and aquatic plants in River Nile and Aswan Reservoir. Egypt. J. Appl. Sci., 8 (2):711-723.

El-Naggar, M. M. ; Hagras, A. E. ; Ogawa, K. ; Hussein, A. B. and ElNaggar, A. M. (2000). A correlation between heavy metals in water and the gifl of Oreochromis niloticus and Tilapia zilli and the intensity of their parasitic monogeneans at Manzalah lake and the River Nile in Egypt. J. Egypt. Ger. Soc. Zool., 32(D): 189-204.

El-Wakeel, S. K. and Wahby, S. D. (1970). Hydrography and chemistry of lake Manzalah, Egypt. Arch. Hydrobiol., 67: 173-200.

Goldberg, E. D. (1965). The oceans as a chemical system. In: The sea, Vol. II, M. N. Hill, Ed., John Wiley Interscience, N. Y., 2$325 \mathrm{pp}$.

Greenwood, N. N. and Earnshaw, A. (1985). Chemistry of the Elements, Pergaman Press Itd. Headington Hill, Oxford Ox3OBW, England.

Hassouna, A. F. A. (1989). Some analytical study on sediments on lake Nasser, River Nile and Aswan Dam Zone Reservoir, M. Sc. Thesis, Fac. Sci., Al. Azhar Univ. 
Hutchinson, G. E. (1957). A treatise on limnology, V. 1. John Wiley and Sons, Inc. New York.

Ibrahim. M. A. ; Mona, M. H. and El-Bokty, E. E. (1997). Abundance and distribution of bottom fauna in lake Manzalah, Egypt. Bull. Nat. Inst. Oceanogra. Fish., A.R.E., 23: 333-349.

Jarup, L. ; Persson, B. ; Edling, C. and Elinder, C. G. (1993). Renal function impairement in workers, previously exposed to cadmium. Nephron, 64: 75-81.

Khalil, M. T. (1990). The physical and chemical environment of lake Manzala, Egypt. Hydrobiologica, 196 (3): 193-199.

Khan, R. A. (1995). Histopathology in winter, flounder, Pleuronectes anericanus, following chronic exposure to crude oil. Bull. Environ. Contam. Toxicol., 54: 297-301.

Khan, R. A. (1998). Influence of petroleum at a refinery terminal on feral winter flounder, Pleuronectes americanus. Bull. Environ. Contam. Toxicol., 61: 770-777.

Khan, R. A. (2000). Comparison of tissue lesions in four species of benthic fish sampled in 1972-1973 and 1997-1998 on the grand banks off Newfoundland. Bull. Environ. Contam. Toxicol., 65: 78-83.

Lliopoulou-georgudaki, J. and Kotsanis, N. (200I). Toxic effects of cadmium and mercury in rainbow trout (Oncorhynchus mykiss): A short-term bioassay. Bull. Environ. Contam. Toxicol., 66: 77-85.

Masoud, M. S. ; Elewa, A. A. and Awad, F. K. (1994). Distribution of some trace metals in river Nile waters. Bull. Fac.Sci., Assuit Univ., pp.67-82.

National Academy of Science (1973). Water Quality Criteria, 1972 V.S. Government printing office, Washington, D.C.U.S.A. 
Prince, N. B. (1994). Chemical Diagnosis in Sediments, Chemical Oceanography, 2 nd ed, Academic Press, 6: pp. i-58.

Robbins, S. ; Angel, M. and Kumar, V. (1981). Inflammation and repair. In: Basic Pharmacology third Edition, pp. 28-46. W. B. Saunders Company, Philadelphia, Torento, Sydney.

Rudolph, A. ; Yanez, R. and Troncoso, L. (2001). Effects of exposure of Oncorhynchus mykiss to the water accomodated fraction of petroleum hydrocarbons. Bull. Environ. Contam. Toxicol., 66: 400-406.

Schaperciaus, W. : Kulow, H. and Schreckeubach, K. (1991). Fish Diseases. Oxonian Press, New Delhi.

Schmidt, H. ; Bernet, D. ; Wahli, T. ; Meier, W. and Burkhardt- Holm, P. (1999). Active biomonitoring with brown trout and rainbow trout in diluted sewage plant effluents. J. Fish Biol., 54: 585596.

Shaheen, A. and Youssef, S. (1978). The effect of cessation of Nile flood on the hydrographic features of lake Manzala, Egypt. Arch. Hydrobiol., 48: 339-397.

Skidmore, J. T. (1964). Toxicity of zinc compounds to , aquatic animals, with special references to fish. Quart. Rev. Biol., 39 (3): 227 248.

Singhal, R. N. and Jain, M. (1997). Cadmium-induced changes in the histology of kidneys in common carp, Cyprinus carpio (Cyprinidae). Bull. Environ. Contam. Toxicol., 58: 456-462.

Toews, D. and Ishak, M. (1984). Fishery transformation of lake Manzala, a brakish Egyptian Delta lake, in response to anthropological and environmental factors during the period 1920-1980. G. F. C. M., (Studies and Review). 61(1): 347-402.

Wahby, S. D. ; Youssef, S. F. and Bishara, N. F. (1972). Further studies on the hydrography and chemistry of lake Manzalah. Bull. Inst. Oceanogr. And Fish. A.R.E., 2: 401-422. 
Table( 1 ): Seasonal variations of Iron concentration ( $\mathrm{mg} / \mathrm{l})$ in the studied area in Lake Manzalah in the period from Autumn 2000 to Summer 2001.

\begin{tabular}{|c|c|c|c|c|c|c|}
\hline 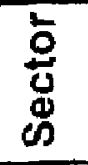 & sogs & Autumn & Winter & Spring & Summer & $\begin{array}{l}\text { Regional } \\
\text { average }\end{array}$ \\
\hline \multirow{4}{*}{$\begin{array}{l}\overline{\bar{g}} \\
\overline{\tilde{g}} \\
\dot{d}\end{array}$} & 1 & 1.045 & 1.040 & 2.351 & 1.693 & 1.532 \\
\hline & 2 & 1.410 & 0.891 & 2.179 & 2.123 & 1.651 \\
\hline & 3 & 1.068 & 1.639 & 0.597 & 9.794 & $1-025$ \\
\hline & 4 & 1.648 & 2.190 & 0.799 & 0.804 & 1.360 \\
\hline \multirow{3}{*}{$\begin{array}{l}\bar{\Sigma} \\
\text { D্ } \\
\text { J }\end{array}$} & 5 & 1.091 & 0.432 & 0.799 & 0.602 & 0.731 \\
\hline & 6 & 0.334 & 0.362 & 0.490 & 0.313 & 0.375 \\
\hline & 7 & 1.490 & 1.398 & 2.239 & 0.859 & 1.497 \\
\hline \multirow{3}{*}{ 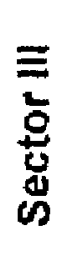 } & 8 & 0.529 & 0.515 & 2.942 & 0.516 & 1.126 \\
\hline & 9 & 0.260 & 0.460 & 0.657 & 0.228 & 0.401 \\
\hline & 10 & 0.223 & 0.181 & 0.541 & 0.288 & 0.308 \\
\hline \multirow{2}{*}{ 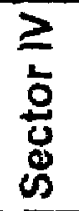 } & 11 & 0.241 & 0.163 & 0.728 & 0.288 & 0.355 \\
\hline & 12 & 0.090 & 0.111 & 0.455 & 0.197 & 0.213 \\
\hline \multicolumn{2}{|c|}{ Annual average } & 0.786 & 0.782 & 1.231 & 0.725 & 0.881 \\
\hline
\end{tabular}


Table ( 2 ): Seasonal variations of Manganese"Mn" Concentration (mg/l) in the studied area in Lake Manzalah in the period from Autumn 2000 to Summer 2001

\begin{tabular}{|c|c|c|c|c|c|c|}
\hline 哭 & 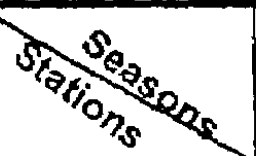 & Autumn & Winter & Spring & Summer & $\begin{array}{l}\text { Regional } \\
\text { average }\end{array}$ \\
\hline \multirow{4}{*}{$\begin{array}{l}\overline{0} \\
\text { ¿ }\end{array}$} & 1 & 0.379 & 0.252 & 0.290 & 0.265 & 0.297 \\
\hline & 2 & 0.547 & 0.363 & 0.364 & 0.153 & 0.357 \\
\hline & 3 & 0.353 & 0.282 & -0.256 & 0.360 & 0.313 \\
\hline & 4 & 0.395 & 0.316 & 0.232 & 0.390 & 0.333 \\
\hline \multirow{3}{*}{ 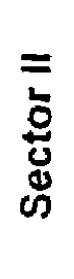 } & 5 & 0.627 & 0.113 & 0.079 & 0.086 & 0.226 \\
\hline & 6 & 0.168 & 0.105 & 0.193 & 0.095 & 0.140 \\
\hline & 7 & 0.129 & 0.187 & 0.184 & 0.181 & 0.170 \\
\hline \multirow{3}{*}{ 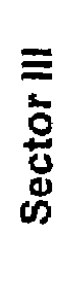 } & 8 & 0.068 & 0.077 & 0.143 & 0.067 & 0.089 \\
\hline & 9 & 0.066 & 0.145 & 0.119 & 0.097 & 0.107 \\
\hline & 10 & 0.065 & 0.160 & 0.129 & 0.088 & 0.111 \\
\hline \multirow{2}{*}{ 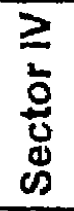 } & 11 & 0.021 & 0.050 & 0.036 & 0.025 & 0.033 \\
\hline & 12 & 0.021 & 0.027 & 0.027 & 0.048 & 0.031 \\
\hline \multicolumn{2}{|c|}{ Annual average } & 0.237 & 0.173 & 0.171 & 0.155 & 0.184 \\
\hline
\end{tabular}


Table ( 3 ): Seasonal variations of Copper "Cu" Concentration (mg/l) in the studied area in Lake Manzalah in the period from Autumn 2000 to Summer 2001.

\begin{tabular}{|c|c|c|c|c|c|c|}
\hline 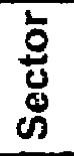 & 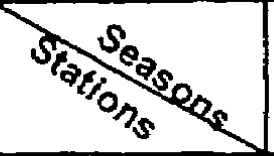 & Autumn & Winter & Spring & Summer & $\begin{array}{l}\text { Regional } \\
\text { average }\end{array}$ \\
\hline \multirow{4}{*}{ 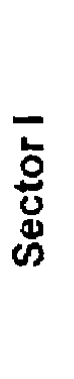 } & 1 & 0.072 & 0.033 & 0.021 & 0.015 & 0.035 \\
\hline & 2 & 0.047 & 0.016 & 0.015 & 0.015 & 0.023 \\
\hline & 3 & 0.047 & 0.088 & 0.015 & 0.033 & 0.046 \\
\hline & 4 & 0.060 & 0.058 & 0.013 & 0.018 & 0.037 \\
\hline \multirow{3}{*}{ 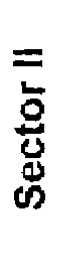 } & 5 & 0.040 & 0.044 & 0.138 & 0.029 & 0.063 \\
\hline & 6 & 0.015 & 0.015 & 0.156 & 0.010 & 0.049 \\
\hline & 7 & 0.041 & 0.037 & 0.015 & 0.013 & 0.027 \\
\hline \multirow{3}{*}{ 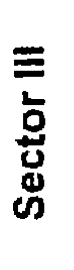 } & 8 & 0.157 & 0.037 & 0.190 & 0.017 & 0.100 \\
\hline & 9 & 0.011 & 0.013 & 0.013 & 0.029 & 0.017 \\
\hline & 10 & 0.008 & 0.046 & 0.022 & 0.018 & 0.024 \\
\hline \multirow{2}{*}{ 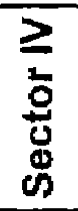 } & 11 & 0.015 & 0.063 & 0.008 & 0.011 & 0.024 \\
\hline & 12 & 0.015 & 0.018 & 0.007 & 0.012 & 0.013 \\
\hline \multicolumn{2}{|c|}{ Annual average } & 0.044 & 0.039 & 0.051 & 0.018 & 0.038 \\
\hline
\end{tabular}


Shadia M. Kadry et al.

Table( 4 ): Seasonal variations of Zinc" $Z n^{\prime \prime}$ Concentration (mg/l) in the studied area in Lake Manzalah in the period from Autmn 2000 to Summer 2001.

\begin{tabular}{|c|c|c|c|c|c|c|}
\hline 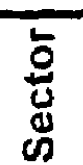 & Sos/ogsege & Autumn & Winter & Spring & Summer & $\begin{array}{l}\text { Regional } \\
\text { average }\end{array}$ \\
\hline \multirow{4}{*}{ 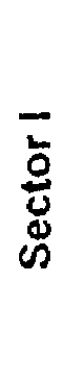 } & 1 & 0.077 & 0.008 & 0.053 & 0.063 & 0.050 \\
\hline & 2 & 0.019 & 0.010 & 0.025 & 0.000 & 0.014 \\
\hline & 3 & 0.112 & 0.026 & 0.028 & 0.009 & 0.044 \\
\hline & 4 & 0.173 & 0.026 & 0.017 & 0.006 & 0.056 \\
\hline \multirow{3}{*}{ 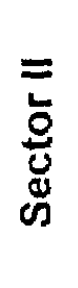 } & 5 & 0.138 & 0.020 & 0.059 & 0.006 & 0.056 \\
\hline & 6 & 0.000 & 0.024 & 0.008 & 0.000 & 0.008 \\
\hline & 7 & 0.036 & 0.013 & 0.005 & 0.010 & 0.016 \\
\hline \multirow{3}{*}{ 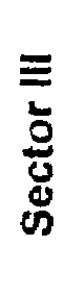 } & 8 & 0.051 & 0.016 & 0.093 & 0.050 & 0.053 \\
\hline & 9 & 0.000 & 0.017 & 0.003 & 0.073 & 0.023 \\
\hline & 10 & 0.000 & 0.013 & 0.008 & 0.004 & 0.006 \\
\hline \multirow{2}{*}{ 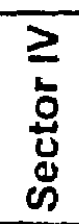 } & 11 & 0.014 & 0.054 & 0.005 & 0.005 & 0.020 \\
\hline & 12 & 0.020 & 0.000 & 0.006 & 0.003 & 0.007 \\
\hline \multicolumn{2}{|c|}{ Annual average } & 0.053 & 0.016 & 0.026 & 0.019 & 0.029 \\
\hline
\end{tabular}


Table( 5 ): Seasonal variations of Lead"Pb" Concentration $(\mathrm{mg} / \mathrm{l})$ in the studied area in Lake Manzalah in the period from Autumn 2000 to Summer 2001.

\begin{tabular}{|c|c|c|c|c|c|c|}
\hline $\begin{array}{l}\text { 总 } \\
\text { ơ }\end{array}$ & 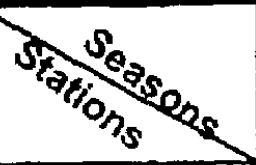 & Autumn & Winter & Spring & Summer & $\begin{array}{c}\text { Regional } \\
\text { average }\end{array}$ \\
\hline \multirow{4}{*}{ 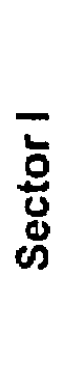 } & 1 & 0.035 & 0.019 & 0.004 & 0.013 & 0.018 \\
\hline & 2 & 0.049 & 0.012 & 0.002 & 0.000 & 0.016 \\
\hline & 3 & 0.022 & 0.022 & 0.020 & 0.009 & 0.018 \\
\hline & 4 & 0.022 & 0.008 & 0.000 & 0.012 & 0.011 \\
\hline \multirow{3}{*}{ 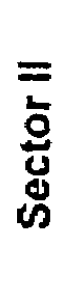 } & 5 & 0.046 & 0.030 & 0.232 & 0.037 & 0.086 \\
\hline & 6 & 0.006 & 0.045 & 0.019 & 0.000 & 0.018 \\
\hline & 7 & 0.000 & 0.014 & 0.000 & 0.000 & 0.004 \\
\hline \multirow{3}{*}{ 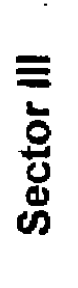 } & 8 & 0.196 & 0.022 & 0.340 & 0.232 & 0.198 \\
\hline & 9 & 0.022 & 0.008 & 0.012 & 0.005 & 0.012 \\
\hline & 10 & 0.000 & 0.049 & 0.018 & 0.000 & 0.017 \\
\hline \multirow{2}{*}{ 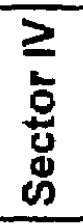 } & 11 & 0.000 & 0.039 & 0.003 & 0.000 & 0.011 \\
\hline & 12 & 0.000 & 0.012 & 0.009 & 0.000 & 0.006 \\
\hline \multicolumn{2}{|c|}{ Annual average } & 0.033 & 0.023 & 0.055 & 0.026 & 0.034 \\
\hline
\end{tabular}


Shadia M. Kadry et al.

Table(6): Seasonal variations of Cadmium" Cd" Concentration (mg/l) in the studied area in Lake Manzalah in the period from Autumn 2000 to Summer 2001.

\begin{tabular}{|c|c|c|c|c|c|c|}
\hline 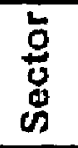 & ${ }_{9} s_{o_{s}} e_{e_{2}}$ & Autumn & Winter & Spring & Summer & $\begin{array}{l}\text { Regional } \\
\text { average }\end{array}$ \\
\hline \multirow{4}{*}{ 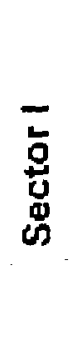 } & 1 & 0.040 & 0.000 & 0.000 & 0.000 & 0.010 \\
\hline & 2 & 0.004 & 0.000 & 0.000 & 0.000 & 0.001 \\
\hline & 3 & 0.015 & .0 .000 & 0.000 & 0.000 & 0.004 \\
\hline & 4 & 0.001 & 0.068 & 0.000 & 0.000 & 0.018 \\
\hline \multirow{3}{*}{ 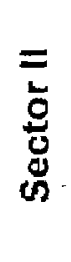 } & 5 & 0.017 & 0.002 & 0.035 & 0.003 & 0.014 \\
\hline & 6 & 0.018 & 0.000 & 0.000 & 0.000 & 0.005 \\
\hline & 7 & 0.004 & 0.001 & 0.004 & 0.000 & 0.002 \\
\hline \multirow{3}{*}{ 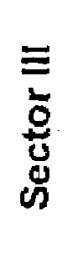 } & 8 & 0.020 & 0.000 & 0.047 & 0.031 & 0.025 \\
\hline & 9 & 0.019 & 0.000 & 0.000 & 0.002 & 0.005 \\
\hline & 10 & $0.000^{\circ}$ & 0.003 & 0.000 & 0.000 & 0.001 \\
\hline \multirow{2}{*}{ 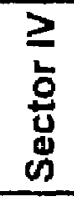 } & 11 & 0.004 & 0.049 & 0.000 & 0.000 & 0.013 \\
\hline & 12 & 0.004 & 0.001 & 0.000 & 0.000 & 0.001 \\
\hline \multicolumn{2}{|c|}{ Annual average } & 0.012 & 0.010 & 0.007 & 0.003 & 0.008 \\
\hline
\end{tabular}




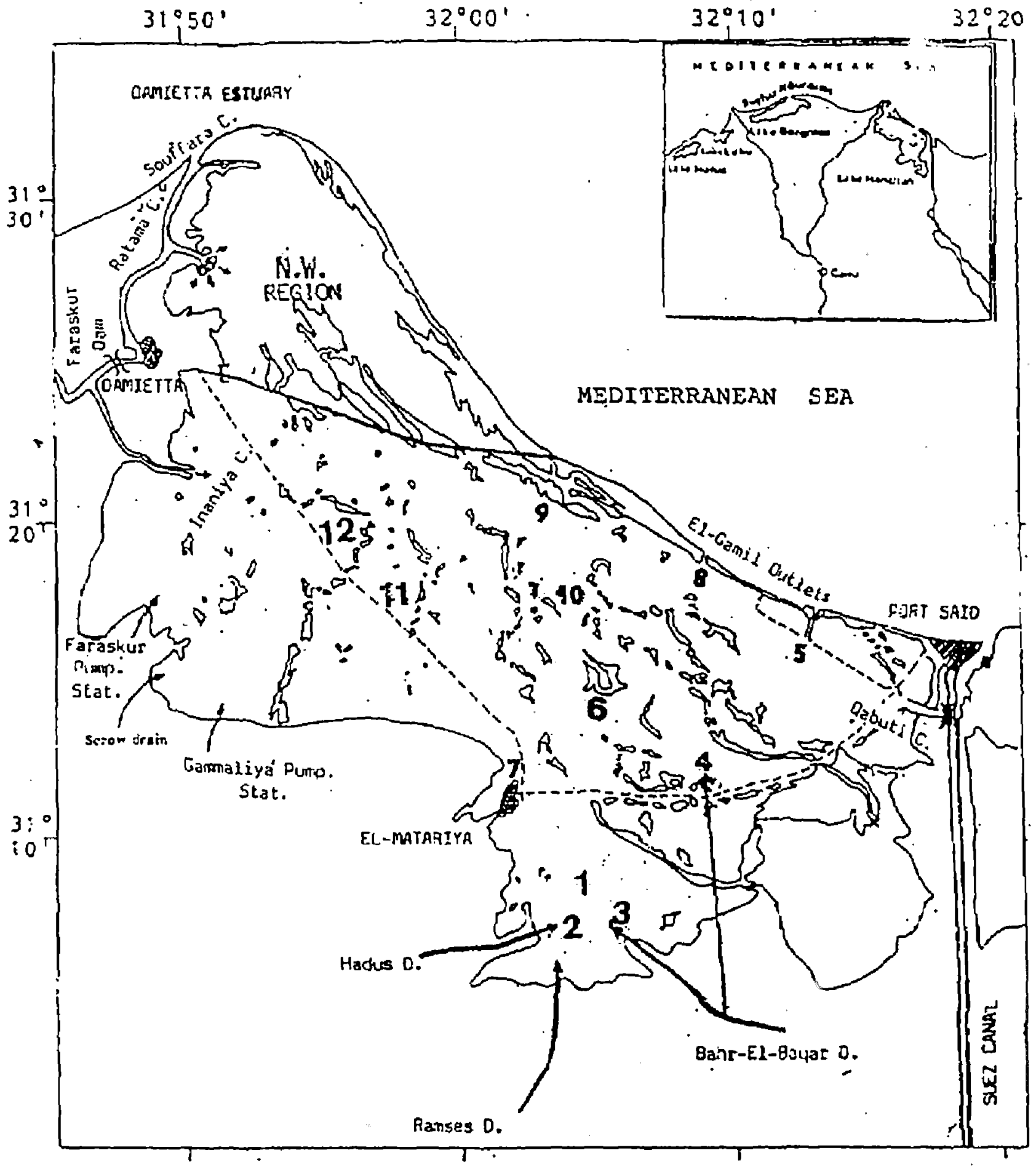

Figure 1. Lake Manzalah showing different zones, drains and canals. 

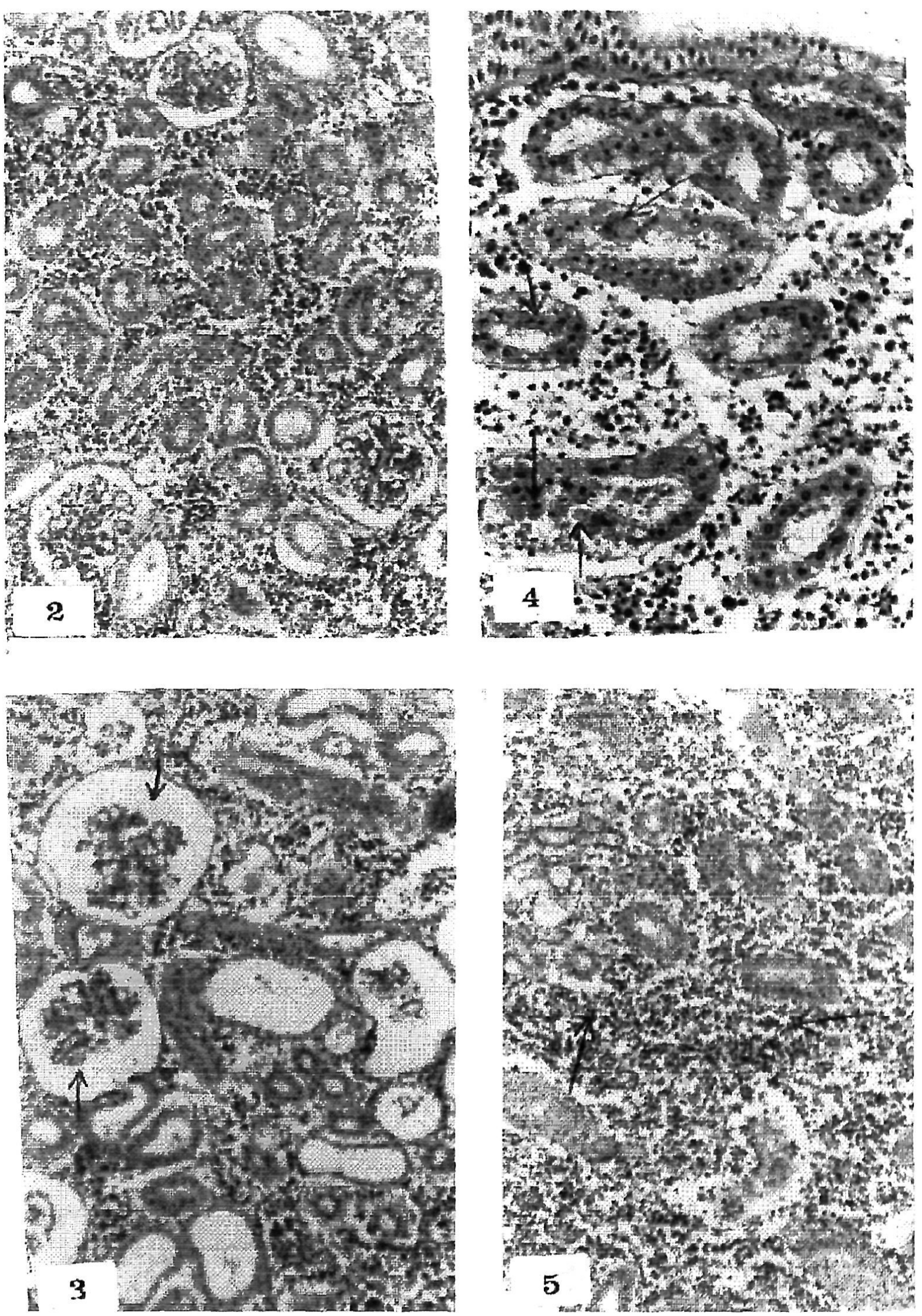


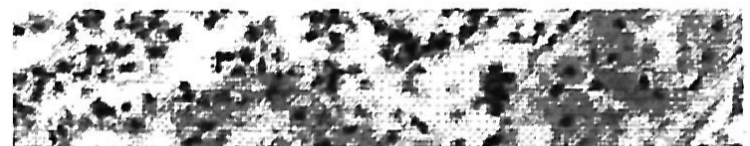

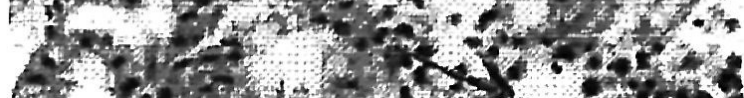

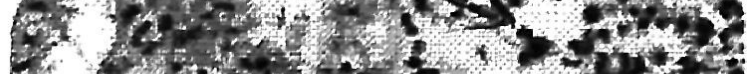

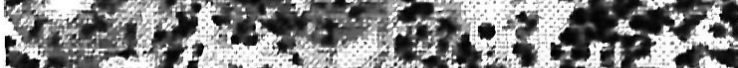

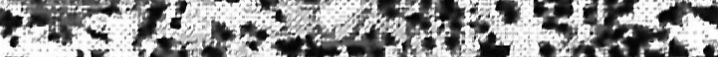

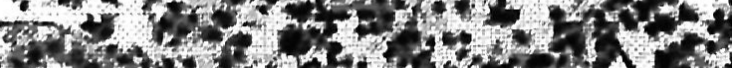

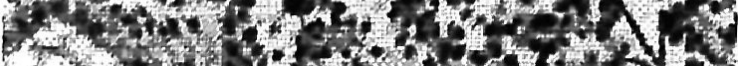

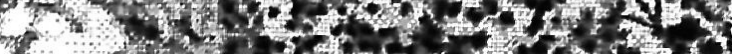

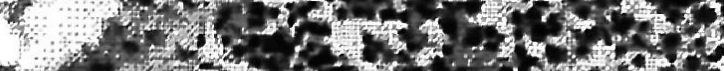

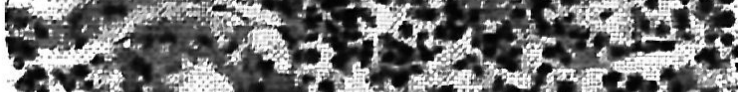

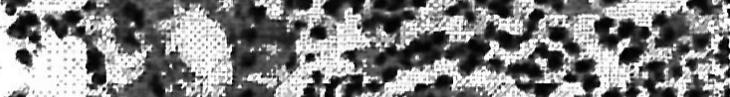
4. 3.

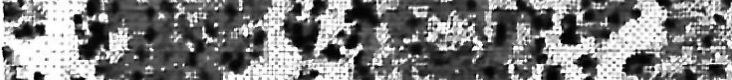

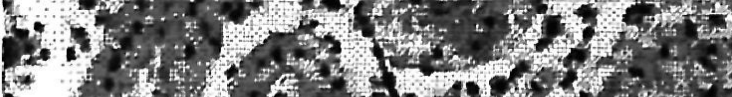

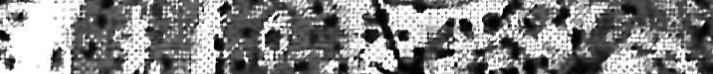

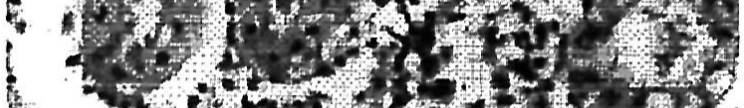

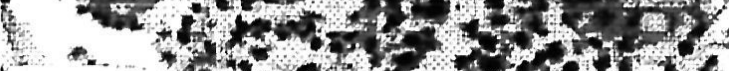

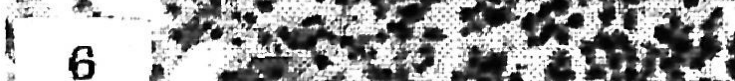

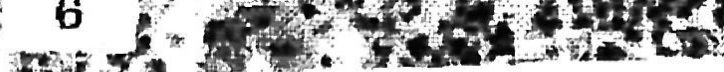

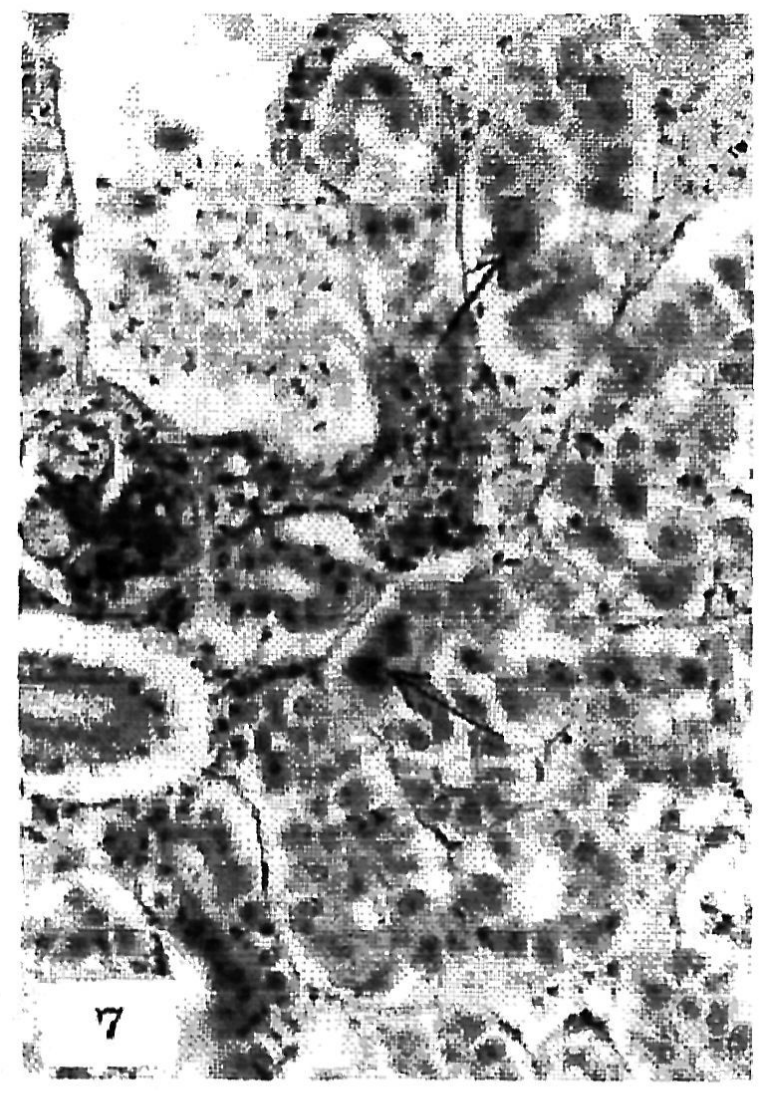

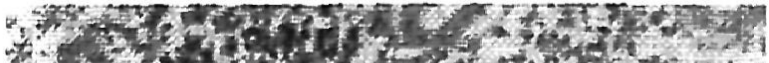

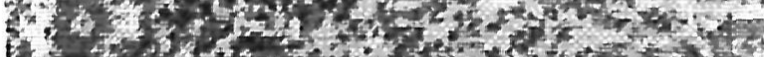

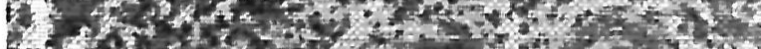

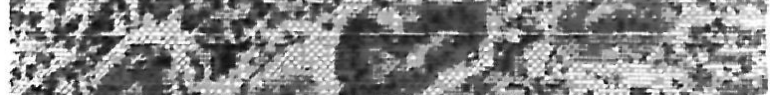

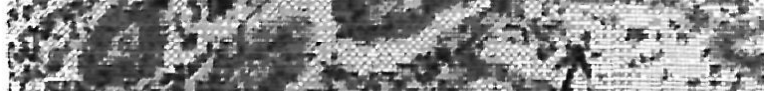

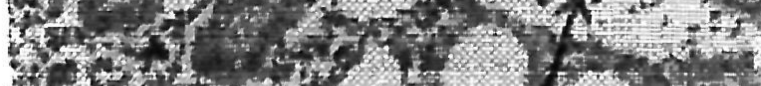
C.t.

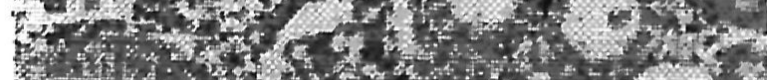

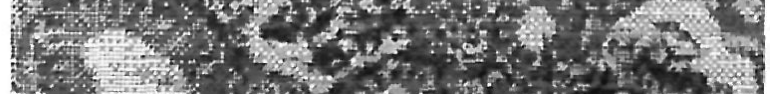

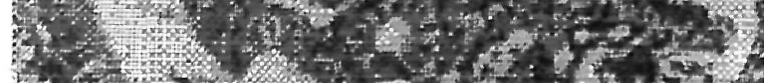

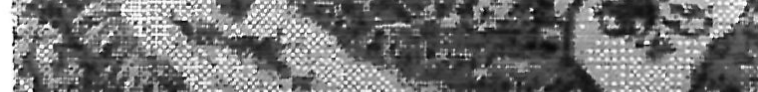

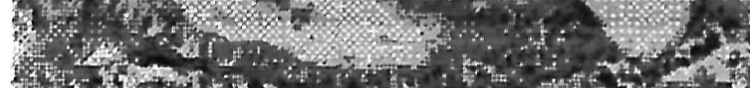

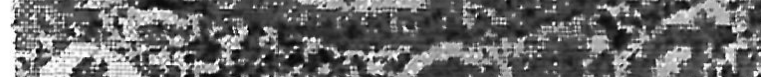

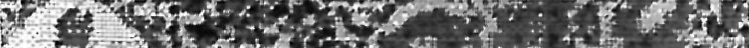

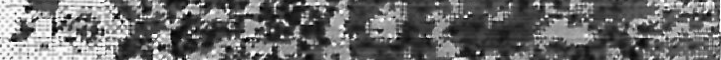

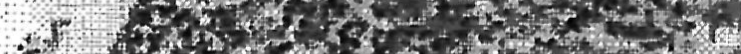

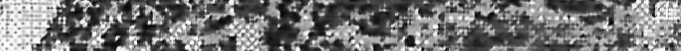

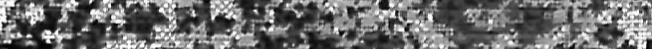

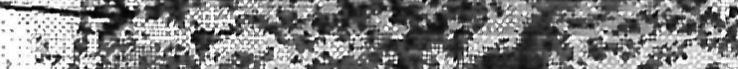

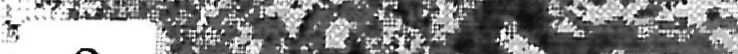

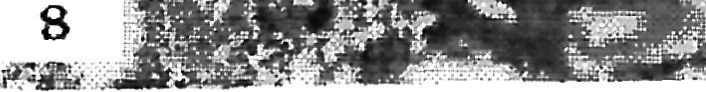

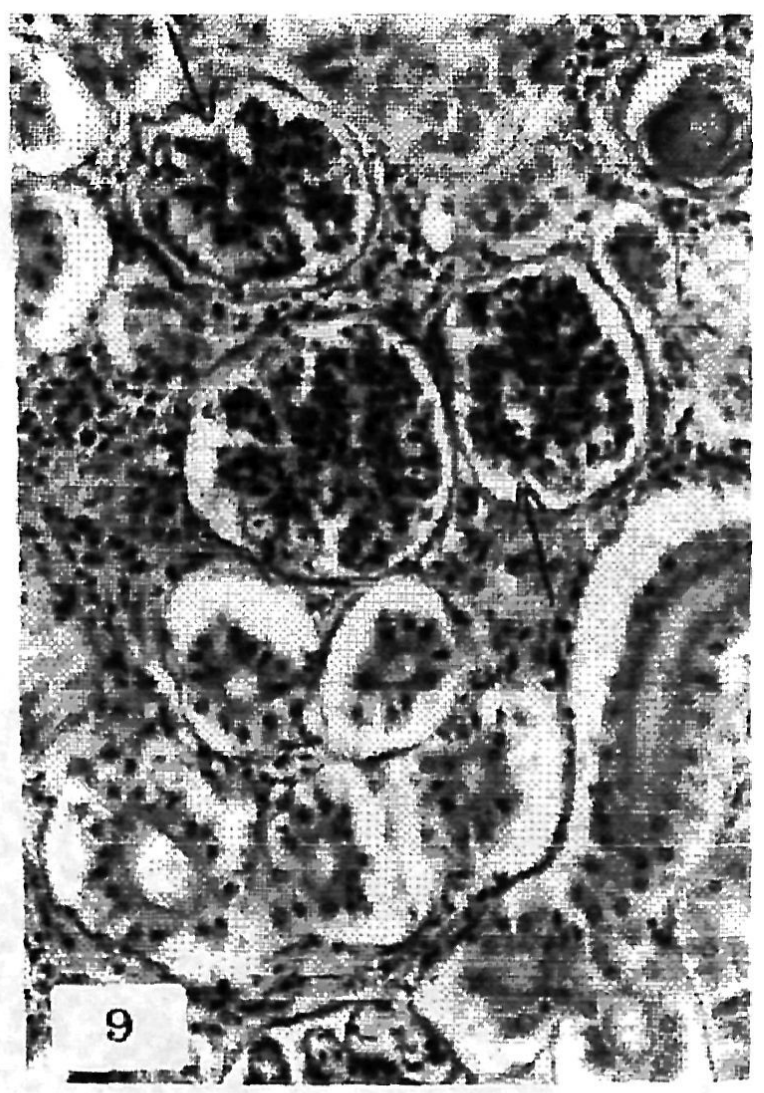



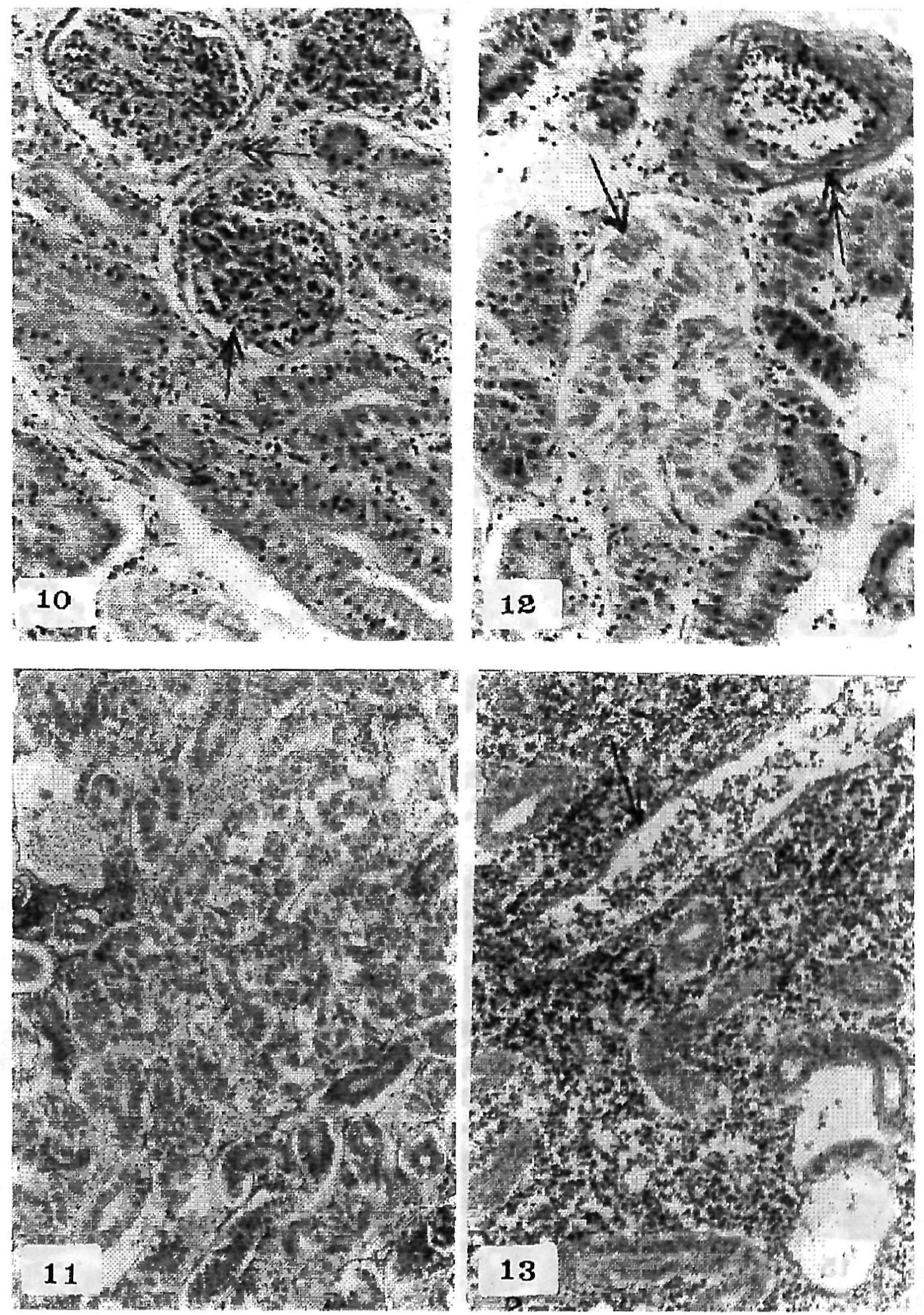

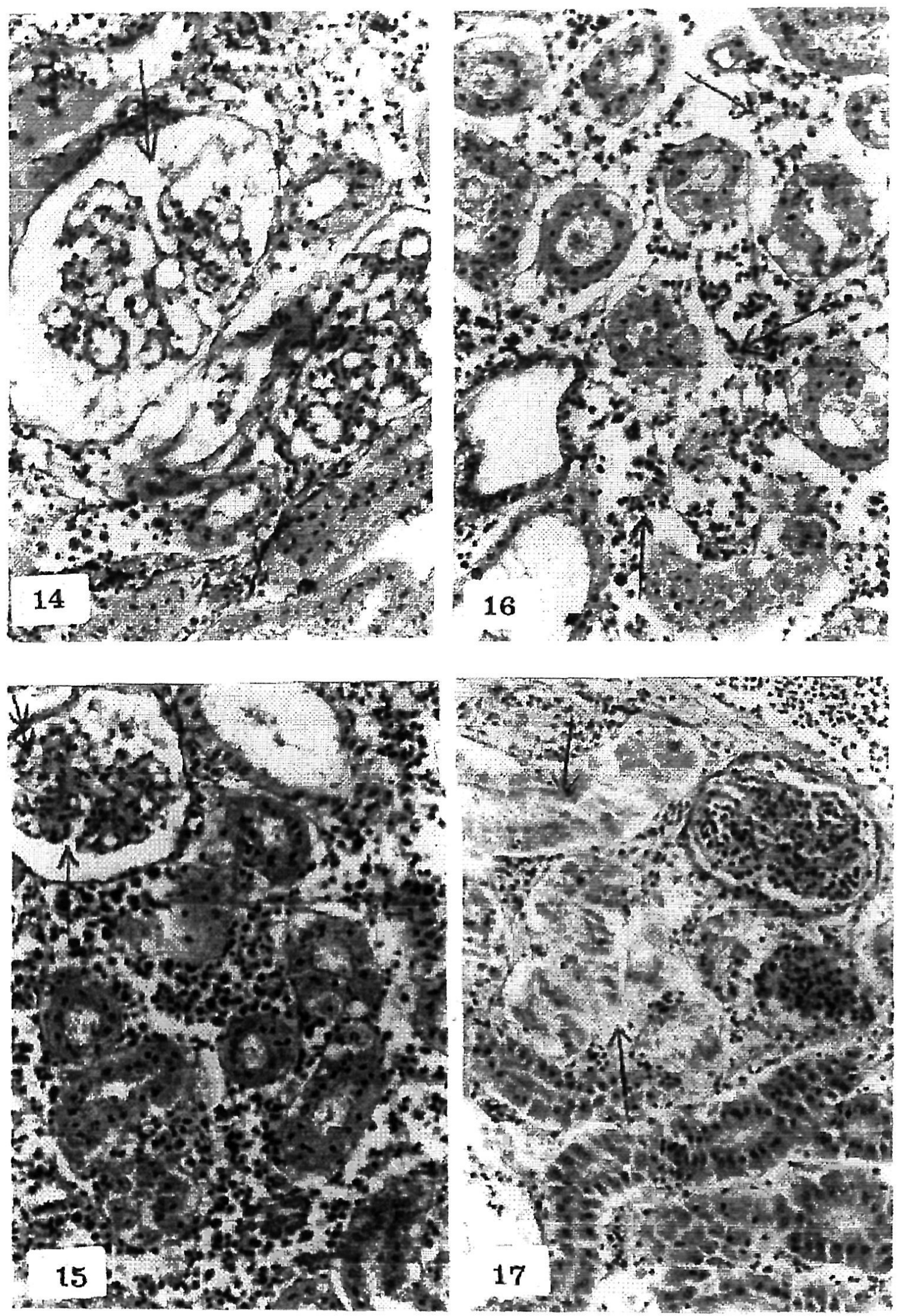